\title{
Impact of Lake Gopło on low-flow regime of the upper Noteć river
}

\author{
Edmund Tomaszewski
}

Department of Hydrology and Water Management, Faculty of Geographical Sciences, University of Łódź, 90-139 Łódź, Narutowicza 88, Poland, e-mail: edtom@uni.lodz.pl

\begin{abstract}
The main aim of this study is to make an assessment of the impact of Lake Gopło on a river low-flow regime. Two water gauges were selected, located in an upstream and downstream position to the lake on the River Noteć. On the basis of the daily discharge series from the period 1965-1990, a group of low-flow regime estimators was computed. Analyses involved various aspects of minimum flows and drought streamflow deficits. Comparison of the data between both gauging stations showed the extent of the influence of water management on Lake Gopło on low-flow regime transformation in the River Noteć.
\end{abstract}

Key words: flow regime, hydrological drought, minimal runoff, drought streamflow deficit, Lake Gopło

\section{Introduction}

Lakes have a great impact on rivers flowing through or out of them. This is manifested by the reduction of maximum flows and changes in flood wave time distribution as well as in a resulting increase in low flows. The buffering effect of lake basin retention on river discharge dynamics, especially during recession time has been widely discussed in literature. This phenomenon originates from the relationship between lake retention capacity and flow volume. It may be described by the quotient of basin capacity to annual flow volume (Mikulski 1998). This index was constructed for smoothing runoff assessment in artificial dam reservoirs, however, it could also be applied for lakes if basin capacity is replaced with active retention capacity which is calculated as lake basin volume between the highest and the lowest observed stage (BajkiewiczGrabowska 2002). Such a quantitative approach is useful if high flows and flood wave rooting are analysed because observed events are rather short, have progression and recession phases as well as a source of alimentation that is unambiguous for identification.

Low flow occurrence and dynamics present a more complicated pattern and much longer time evolution (Smakhtin 2001). Therefore links between lake features and low-flow regime components are not obvious and are very often multidirectional. In the literature, the most commonly mentioned effect of lake discharge transformation, generally regarded as positive from an environmental and water management point of view, is smoothing runoff downstream, which slows down the pace of low flow recession as well as increasing the lowest values of flow. The explanation for these processes can be found in the time shift retention of lake basin from wet to dry periods. However, lakes often drain deep groundwater reservoirs, unavailable for river channels. The volume of such a kind of alimentation is not usually extensive but during low-flow periods it may constitute a significant component of river flow. On the other hand, lakes determine higher balance losses connected with evaporation from the open water surface and high transpiration during the summer vegetation season. It is worth noting that the above mentioned processes affect the dynamics of particular low-flow events. On a multiannual scale, especially after a few dry years, streamflow deficits in lake catchments may lead to much more severe hydrological drought in comparison to the other types of catchment. This is because water resources stored in a lake basin may be drained much quicker than in a groundwater reservoir. However, in years following drought, the pace of water resource replenishment in lakes is higher than in ground waters. As a result, the multiannual variation of streamflow deficits is very high (Tomaszewski 2012).

Additional water shortage may be expected when lakes are used for water management purposes (irrigation, water supply, fishery, hydropower etc.). Lakes are frequently dammed in order to enhance storage capacity. It is also worth pointing out that all water manage- 


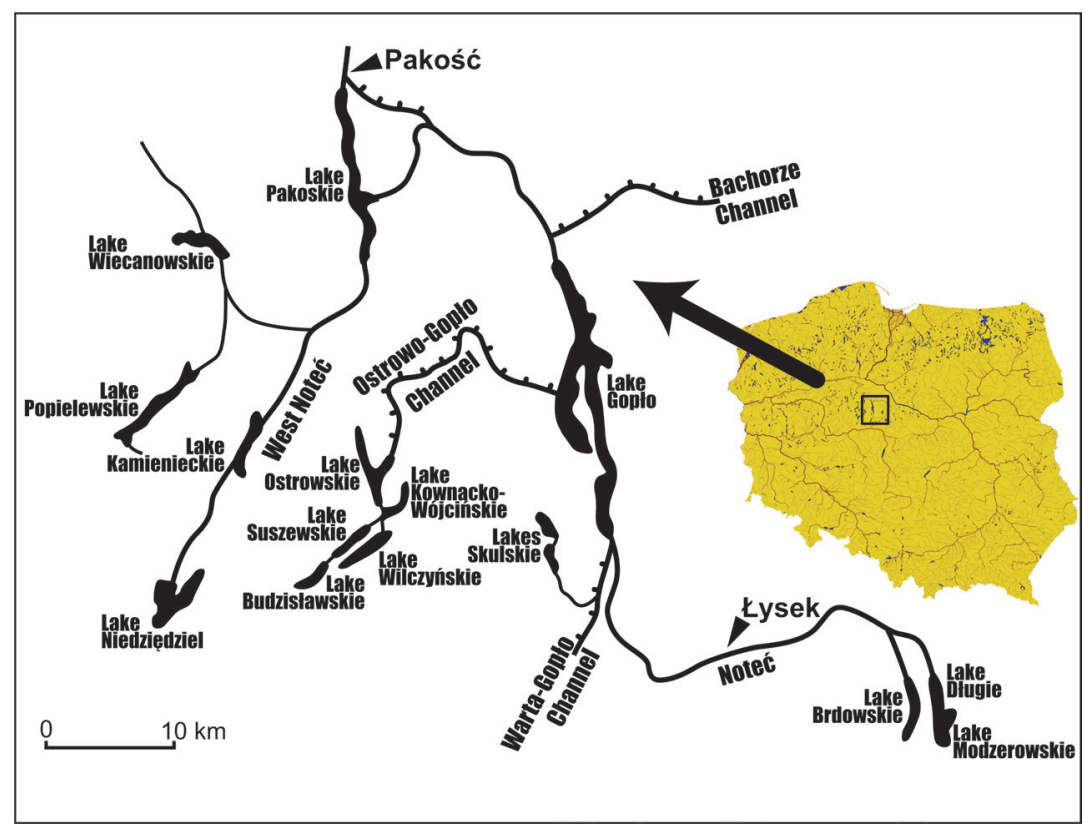

Fig. 1. Location of the research water gauges

ment functions are realized upstream in relation to the weir or outflow cross-section of a lake. Therefore, during restricted alimentation periods, fulfilling the needs of the lake users (located before the weir) may exacerbate water shortage downstream. The severity level of hydrological drought depends in such cases on the resistance of lake to water resource recession which may be estimated by the smoothing runoff index.

Damming lakes in the upper Noteć river catchment began in the late 60s of the XX century (Grzes 1972). The main reservoir in this area, located in the axis of main river, is Lake Gopło (Fig. 1). Its surface area by mean water table level (76.82 $\mathrm{m}$ a.s.l.) is equal 21.6 $\mathrm{km}^{2}$. Average basin capacity depends on the method of estimation and varies in range between $76.7-78.5 \mathrm{hm}^{3}$ (Pasławski and Błaszczyk 1970; Piasecki and Skowron 2014). Two lakes in the catchment are dammed significantly. Lake Gopło is dammed in $0.95 \mathrm{~m}$ which creates $21.2 \mathrm{hm}^{3}$ of additional storage capacity and Lake Pakoskie, which has the largest available storage capacity $\left(47.7 \mathrm{hm}^{3}\right)$ and damming height $(4.90 \mathrm{~m})$ in Poland (Marszelewski and Kornaś 2012). Discharges in this lake-river system are also determined by water management. Artificial inputs-outputs of the system pass through the channels: Warta-Gopło, Bachorze and Ostrowo-Gopło. Moreover, due to natural and anthropogenic impact, significant fluctuations and disappearance of lake surface are observed (Marszelewski et al. 2011; Piasecki and Marszelewski 2014).

The aim of this study is to identify which components of the river low-flow regime are modified by water management activity on Lake Gopło. This will involve comparison of the hydrological data from two gauging stations located on the River Noteć: Łysek and Pakość (Fig. 1). It is assumed that differences in the low-flow regime appearing in the catchment between these two gauging stations can be explained by anthropogenic impact. The observation period adopted for this study (1965-1990) excludes the influence of opencast mining dewatering which began in the 90s of the $\mathrm{XX}$ century.

\section{Data and methods}

The basic input data was the daily discharge series from the period 1965-1990, provided by the Insti-

Table 1. Basic characteristics of minimum flows and drought streamflow deficits in the River Noteć (1965-1990). A - catchment area, MeNq - median annual minimum specific flow, MinNq - the lowest observed flow, CvNq - variation coefficient of Nq, MeDWz - median annual relative drought streamflow deficit, $\mathrm{CvDWz}$ - variation coefficient of DWz, RA1(Y) - first autocorrelation coefficient of annual drought streamflow deficits, RA1(M) - first autocorrelation coefficient of monthly drought streamflow deficits

\begin{tabular}{|c|c|c|c|c|c|c|c|c|}
\hline \multirow{2}{*}{ Water-gauge } & \multirow{2}{*}{$\mathrm{A}\left[\mathrm{km}^{2}\right]$} & $\mathrm{MeNq}$ & $\mathrm{MinNq}$ & \multirow{2}{*}{$\mathrm{CvNq}$} & \multirow{2}{*}{ MeDWz [\%] } & \multirow{2}{*}{ CvDWz } & \multirow{2}{*}{$\mathrm{RA} 1(\mathrm{Y})$} & \multirow{2}{*}{ RA1(M) } \\
\hline & & \multicolumn{2}{|c|}{$\left[\mathrm{dm}^{3} \mathrm{~s}^{-1} \mathrm{~km}^{-2}\right]$} & & & & & \\
\hline Łysek & 306.0 & 0.523 & 0.0098 & 0.675 & 8.614 & 1.076 & 0.236 & 0.811 \\
\hline Pakość & 2356.2 & 0.876 & 0.2292 & 0.462 & 6.653 & 1.262 & 0.351 & 0.812 \\
\hline
\end{tabular}




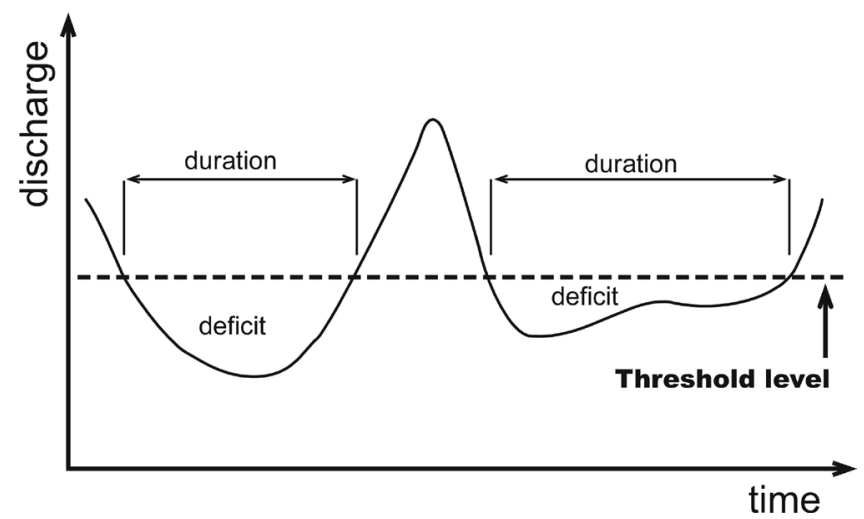

Fig. 2. Basic parameters of a hydrological drought

tute of Meteorology and Water Management in Poland. Data derived from two gauging stations located on the River Noteć: Łysek and Pakość (Fig. 1, Table 1). For initial low-flow analysis, a series of minimum flows at monthly and annual time step were prepared.

The most popular definition of hydrological drought refers to a period during which low flows appear in river channel. Smakhtin refers to the WMO's definition in which the low-flow is a flow of water in a stream during prolonged dry weather (2001). The origin of this phenomenon is determined by restricted alimentation, caused by lack of precipitation and high evapotranspiration in summer or the cutting off of drainage channels by frozen ground during the winter. The length of dry period and the relation between the recession and replenishment rate of groundwater resources have a great impact on the progression of a drought event where its duration and water shortage are the most important factors for the estimation of the level of drought severity.

One of the most common methods for the delimitation of a low-flow event is determination of a threshold level. A period during which discharge attains values below an established limit is defined as a streamflow deficit period. Its two basic parameters are low flow duration and deficit volume (Fig. 2). The lowflow periods were identified on the basis of a threshold level derived from a flow duration curve (Hisdal et al. 2004). As a truncation level, the discharge which refers to 70 -th $\left(\mathrm{Q}_{70}\right)$ percentile was established. This kind of estimator seems to be most appropriate for lake catchments (Tomaszewski 2011).

\section{Results}

\section{Minimum flows}

Minimum value of runoff is an integral part of a low-flow regime. It indicates limitations during recession of flow on the dry weather curve and very often, the regime of a basic groundwater reservoir drained by

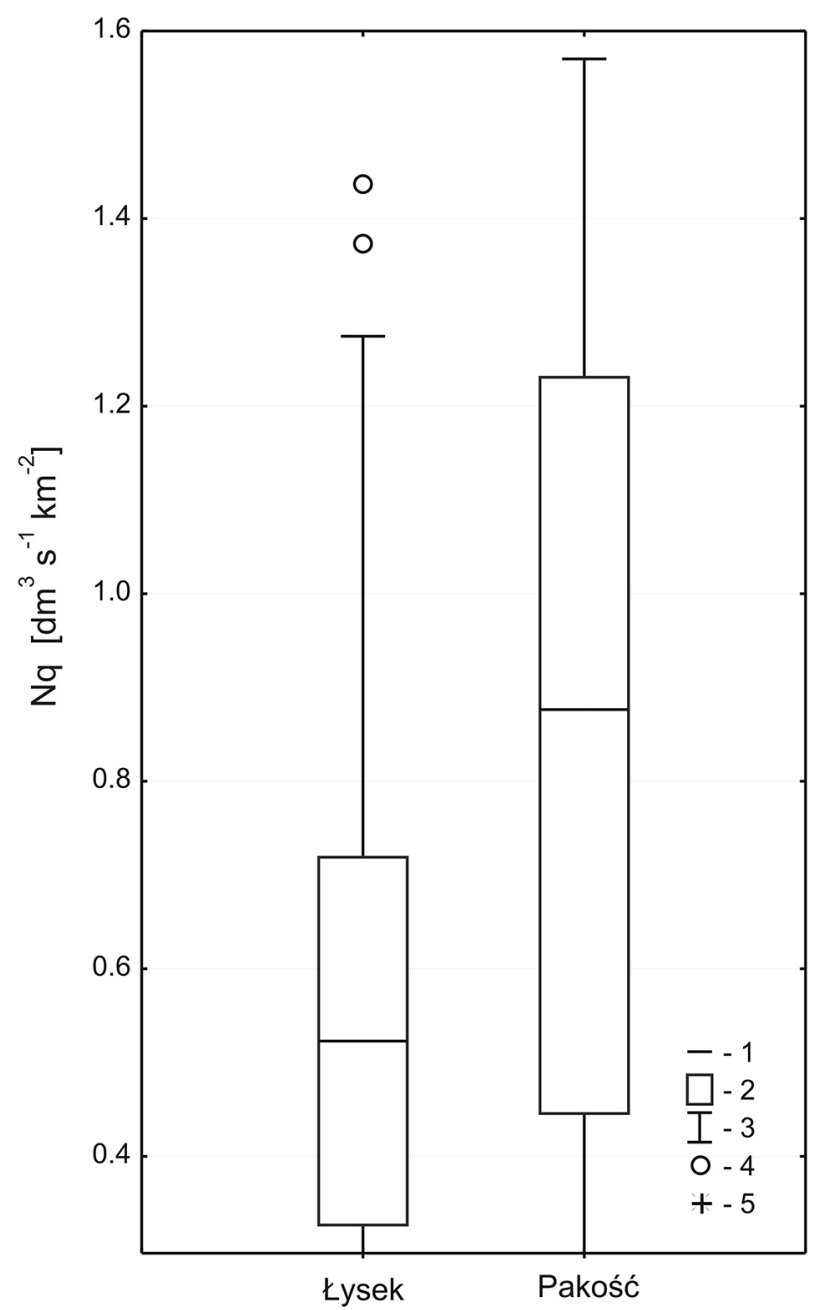

Fig. 3. Distribution of annual minimum specific flow in the River Noteć. Denotations: 1 - median, 2 - range between first and third quartile, 3 - range limited by 1 quartile deviation, 4 - outliers under 1.5 quartile deviation, 5 - extremes over 1.5 quartile deviation

river channels during a drought. Minimum value may also be modified by such factors as lake, wetland or forest retention.

Distribution of the minimum annual specific flow in both gauging stations is rather symmetrical (Fig. 3). This may indicate high similarity in the factors determining the lowest flows as well as the lack of an extra factor on the River Noteć between gauges. All of the computed flow values in this paper are presented as specific runoff in order to compare the quantity of discharging water without the burden of the catchment area. Average minimum flow in Łysek is slightly lower besides having the lowest value (Table 1). This can be explained by the higher lake density in the catchment between Łysek and Pakość. The influence of water management on dammed lakes can be observed in such features of $\mathrm{Nq}$ distribution as higher variation coefficient 


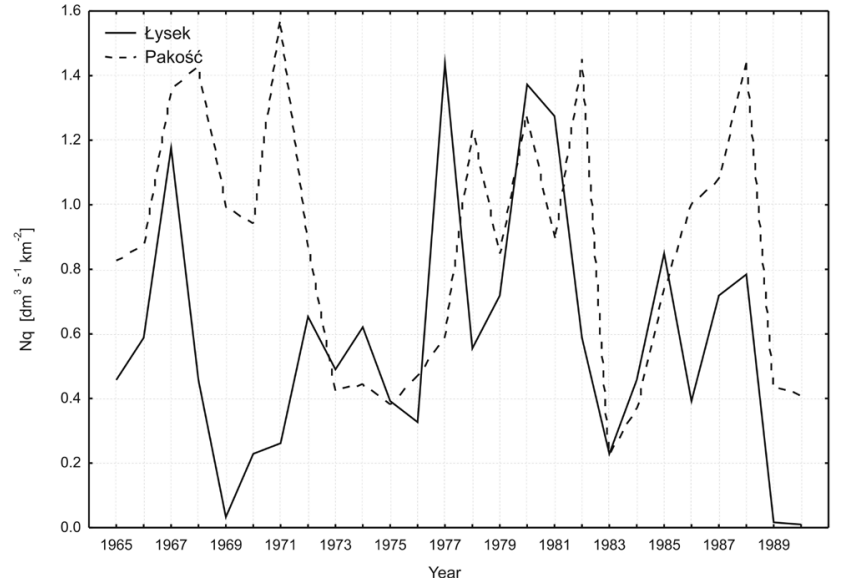

Fig. 4. Annual course of the minimum specific flow in the River Noteć (1965-1990)

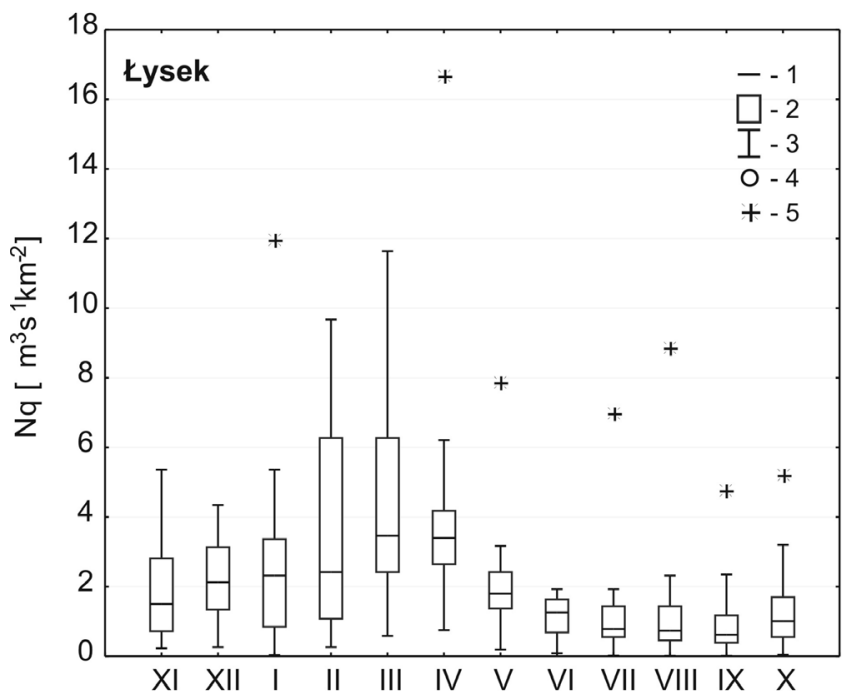

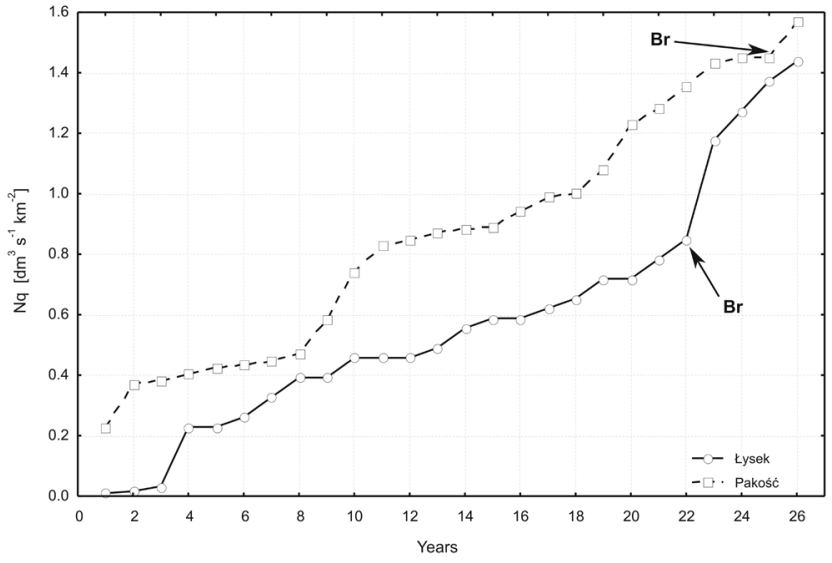

Fig. 5. Non-decreasing series of minimum specific flow at annual step. Denotations: $\mathrm{Br}$ - break point indicating genetic estimator of the threshold level for the beginning of a hydrological drought

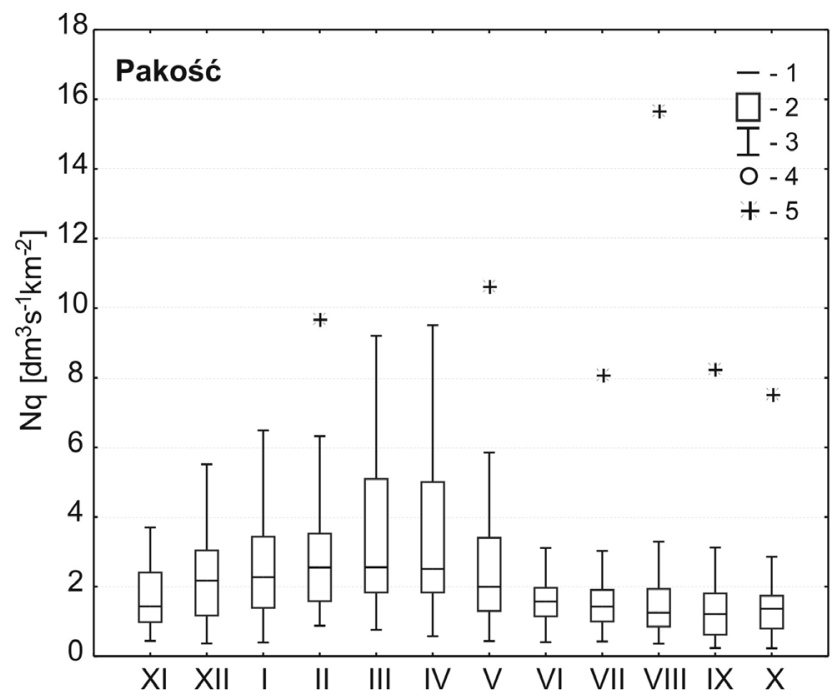

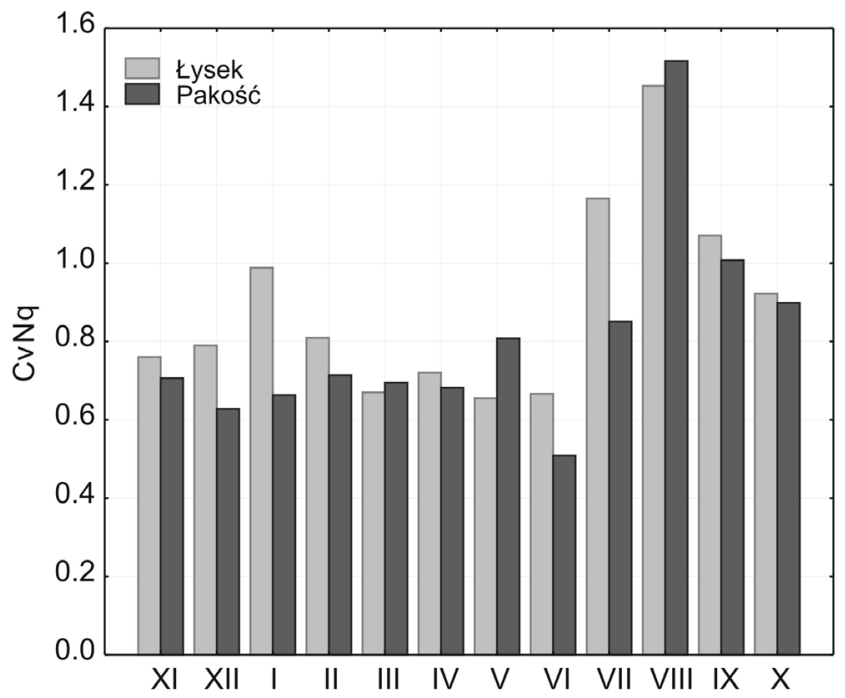

Fig. 6. Distribution of monthly minimum specific flow (Nq) in the River Noteć and its variation coefficient (CvNq). Numerals 1-5 - see Fig. 3 
and wider range between the first and third quartile in Pakość. Differences are not extensive, althoughthey do indicate a multiannual low flow stabilization resulting from an artificial delaying of water resource recession.

Statistical analysis of the annual course of minimum flow proved that there is no statistically crucial linear trend at the significance level equal 0.05 in either of the gauges (Fig. 4). Thus a systematic multiannual component determining minimum runoff value in the period 1965-1990 is lacking, which could be expected in the case of a significant anthropogenic impact on water circulation. The course of both characteristics is more or less synchronous. Local minimums in 19831984 and 1989-1990 are typical for the whole Oder river basin (Jokiel and Stanisławczyk 2012). An interesting period occurred between 1973 and 1976 when minimum annual specific flows in Łysek were higher than in Pakość. The most probable explanation for this is the filling up of newly dammed lakes or reservoirs following restoration or modification to their weirs. It is worth noting that average and minimum water stages in Lake Gopło during these years did not display such a tendency (Marszelewski and Skowron 2011; Piasecki and Skowron 2014).

Analysis of the non-decreasing diagram of annual minimum flows in a multi-year period (Fig. 5) revealed some further interesting points about the lowflow regime. Initially, an assumption was made that minimum runoff, taken as an estimator of the regime of groundwater reservoirs, would demonstrate a linear or quasi linear gradient. However, the breaking of this tendency in the upper part of the diagram indicates the participation of different components of river channel alimentation. This break point can be taken as the upper limitation of groundwater resource renewal as well as the threshold level for hydrological drought (Tomaszewski 2011). The break points appeared on curve at the level $0.85 \mathrm{dm} 3 \mathrm{~s}^{-1} \mathrm{~km}^{-2}$ in Łysek and $1.45 \mathrm{dm}^{3} \mathrm{~s}^{-1}$ $\mathrm{km}^{-2}$ in Pakość. The difference is determined by lake retention capacity. Moreover, 3 "steps" on the curve for Pakość might indicate threshold values connected with water management in dammed lakes.

Distribution of monthly minimum specific flow demonstrates seasonal synchronicity between water gauges (Fig. 6). However, changes in following months as well as seasonal rhythm appear more clearly in Łysek. The buffering function of lake basins in catchment between gauges is also manifested in March and April when minimum runoffs in Pakość are significantly lower than in Łysek. Multiannual variation of monthly minimum flows between November and June is more or less similar, which results in variation coefficients within the range of $0.6-0.8$. Its high variation in summer months emphasizes the role of a very changeable alimentation factor in a low flow regime - precipitation. As a result, this season appears to initiate the most severe hydrological droughts.

\section{Drought streamflow deficits}

On the basis of the defined threshold level, drought streamflow deficit volume for each month and year of the investigated period were calculated. Water shortage capacity, similarly to flow volume, is incomparable due to differentiation in the catchment area. Therefore relative drought streamflow deficit was used (Tomaszewski 2012):

$$
D W \mathrm{n}=\frac{V \mathrm{n}}{V \max } \cdot 100 \%
$$

where: $D W n$ - relative drought streamflow deficit [\%], $V n-$ drought streamflow deficit volume in given period $\left[\mathrm{m}^{3}\right], V \max$ - maximum possible drought streamflow deficit volume in given period (river discharge equal 0$)\left[\mathrm{m}^{3}\right]$.

This index valorises not only streamflow deficit intensity but also indicates the level of drained water resources in the catchment which remain in a hydraulic relationship with low flow. It is worth pointing out that if the index value reaches $100 \%$, discharge in the river channel should be stopped (Fig. 7). This characteristic may be applied as an estimator of hydrological drought severity. Furthermore, it fully guarantees the comparability of results derived from differently sized catchments and is very useful in low-flow analyses for

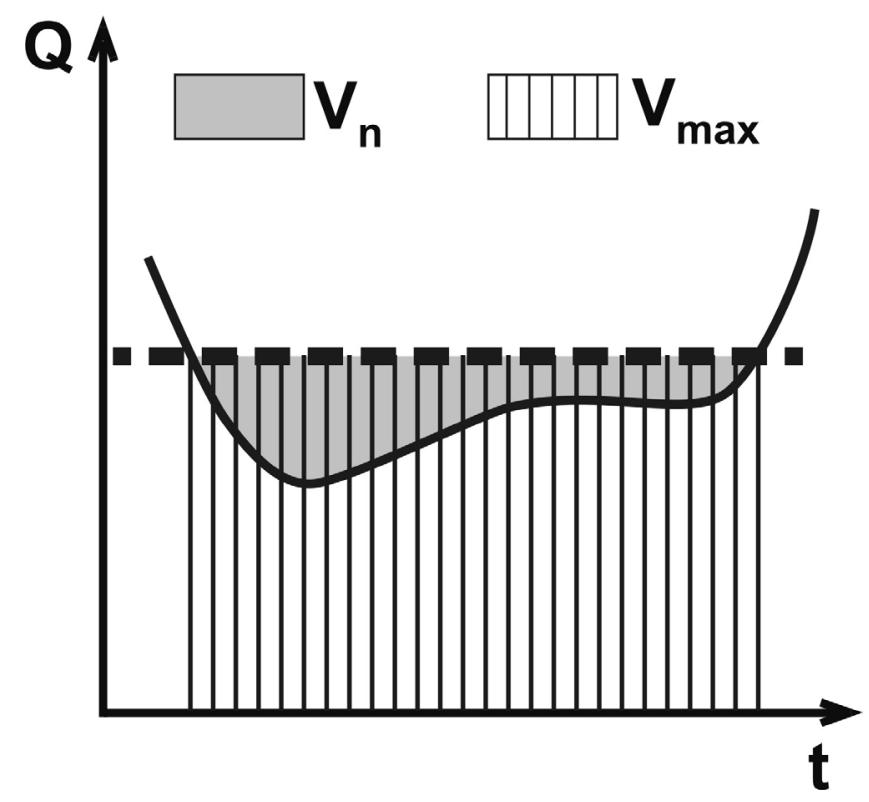

Fig. 7. Graphical illustration of a relative drought streamflow deficit estimation. Denotations: $V \mathrm{n}$ - drought streamflow deficit volume $\left[\mathrm{m}^{3}\right], V \max$ - maximum possible streamflow deficit volume during investigated period, i.e. when discharge value is equal $0\left[\mathrm{~m}^{3}\right]$ 


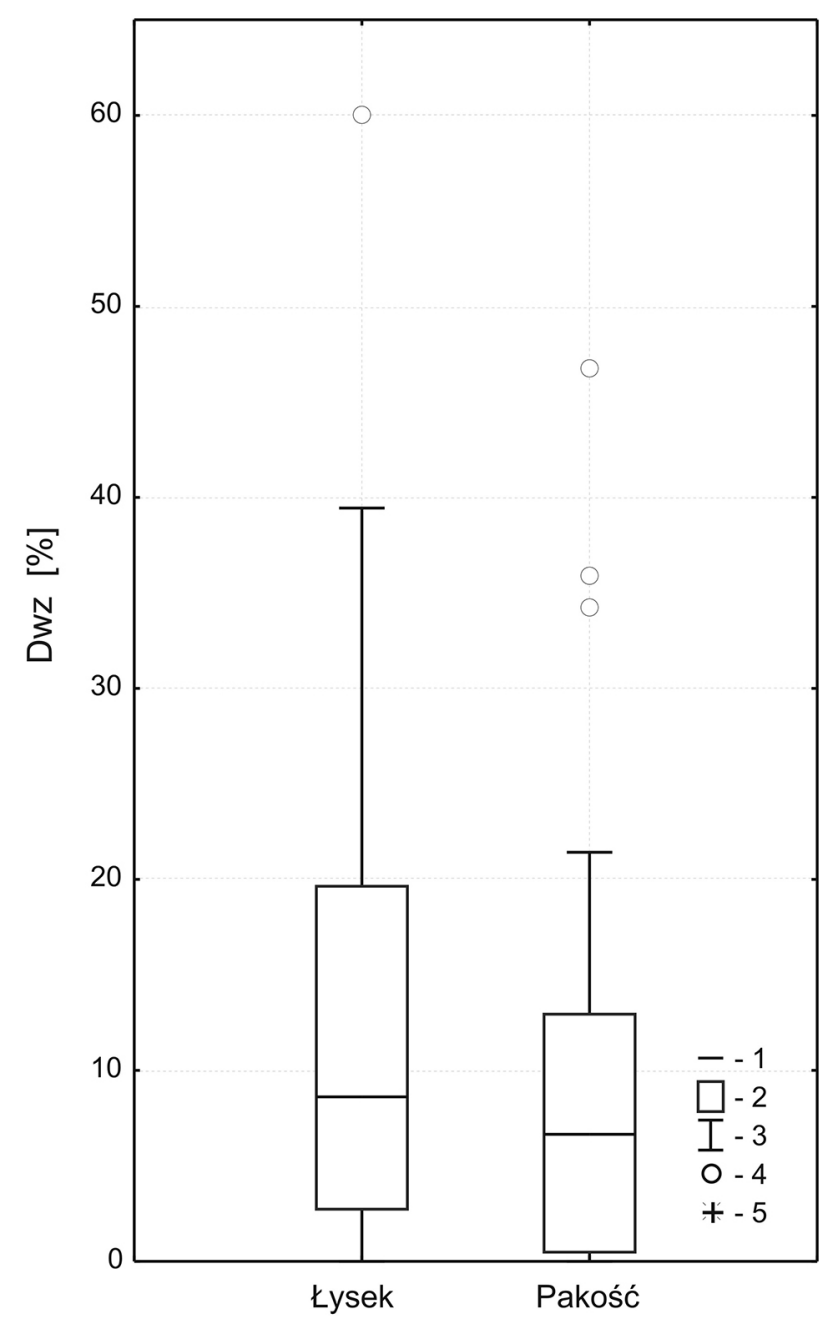

Fig. 8. Distribution of annual relative drought streamflow deficit in the River Noteć. Numerals 1-5 - see Fig. 3

transit rivers because it uses data from a particular hydrometrical channel cross-section only.

Mean relative drought streamflow deficit in both catchments reached a very similar level (Fig. 8, Table 1 ). This means that every year on average, $7-8 \%$ of lowflow resources are drained. However, in extremely dry years this value may reach 60\% in Łysek and a slightly more than $45 \%$ in Pakość. Interquartile ranges are proportional to total ranges and both distributions look rather symmetrical. Thus, it may be concluded that observed differences in DWn are determined by the same factor, which is capacity of lake retention. The multiannual variation coefficient of streamflow deficits is very similar and high (Table 1). Therefore, in river-lake systems, after severe hydrological droughts, years without water shortage appear immediately and there is no tendency to join wet or dry years into groups (Fig. 9). This is primarily because the reaction of the lake systems to dry weather conditions and to the replenishment phase

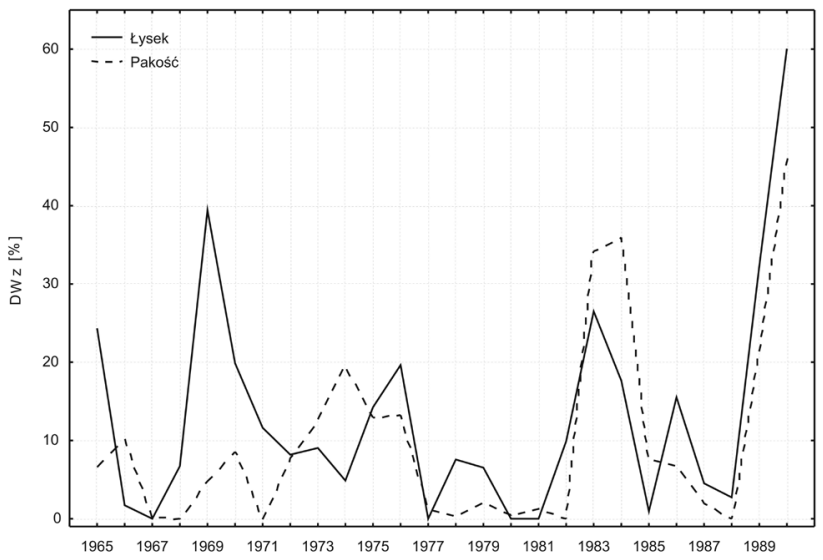

Fig. 9. Annual course of relative drought streamflow deficit in the River Noteć (1965-1990)

is much quicker than in different lowland catchments without lakes but with slow groundwater reservoir recession and renewal pace. Similar results of changeability in both water gauges exclude the water management on Lake Gopło as a significant determinant in this case. It is worth noting that estimated level of streamflow variability is very high here in comparison to Polish lowland catchments (Tomaszewski 2012).

The annual course of relative drought streamflow deficit does not demonstrate any regularity which might be connected with anthropopression on Lake Gopło (Fig. 9). Statistically significant linear trends do not exist. It is interesting that in 1983 and 1984 when very low annual minimum flows were observed (see Fig. 4), relative deficits in Pakość are higher than in Łysek which could indicate a non-linear development of severe hydrological droughts in the catchment between the observed gauges.

Monthly distribution of relative drought streamflow deficit is strictly determined by hydrological cycle (Fig. 10). The lowest deficits occur in the spring season as an effect of thaw alimentation. The summer months determine high deficits caused by lack of precipitation enhanced by evaporation and transpiration. Summer low-flow events might be prolonged well into the autumn season. Winter hydrological droughts occur very rarely. Seasonal distribution of the variation coefficient demonstrates a reversed order. As a result, the stability of a low-flow regime is determined by hydrological droughts of summer half-year. It is interesting that between March and June average relative streamflow deficits in Pakość are higher than in Łysek. Such differences are probably caused by the replenishment time of dammed retention in Lake Gopło and other lakes in the catchment which leads to temporary low-flow periods downstream on the Pakość gauging station. 

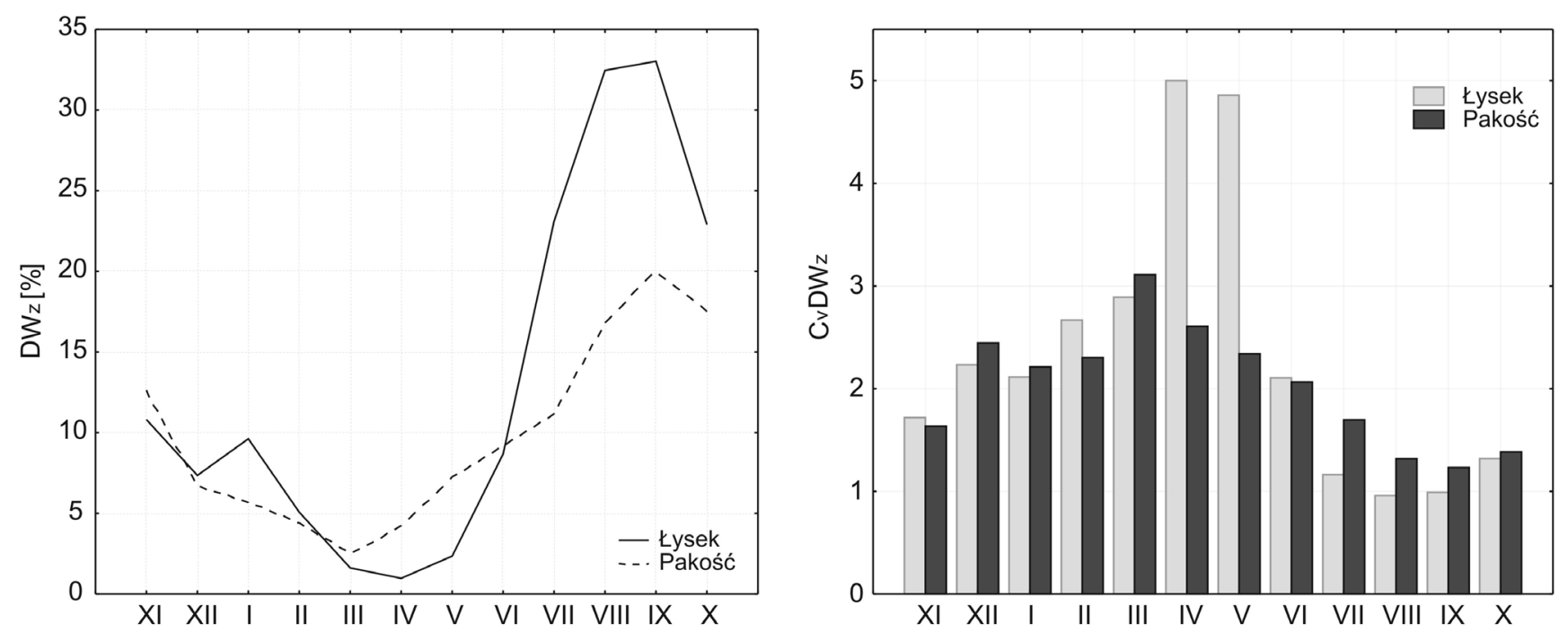

Fig. 10. Distribution of monthly relative drought streamflow deficit (DWz) in the River Noteć and its variation coefficient (CvDWz)

The analysis of streamflow shortage inertia, based on autocorrelation (Kendall 1984), gave promising results. The first autocorrelation coefficient (shift = 1 , one year in this case) revealed information concerning low flow formation that is transmitted year by year. In both cases its value was not very strong but statisti- cally significant (Fig. 11) and it seems to be determined by the high multiannual variability of lake regime and non-synchronous changes of retention in groundwater reservoirs. Analysis of the autocorrelation function in successive lags indicates the occurrence of some separated periods with positive and negative coefficients
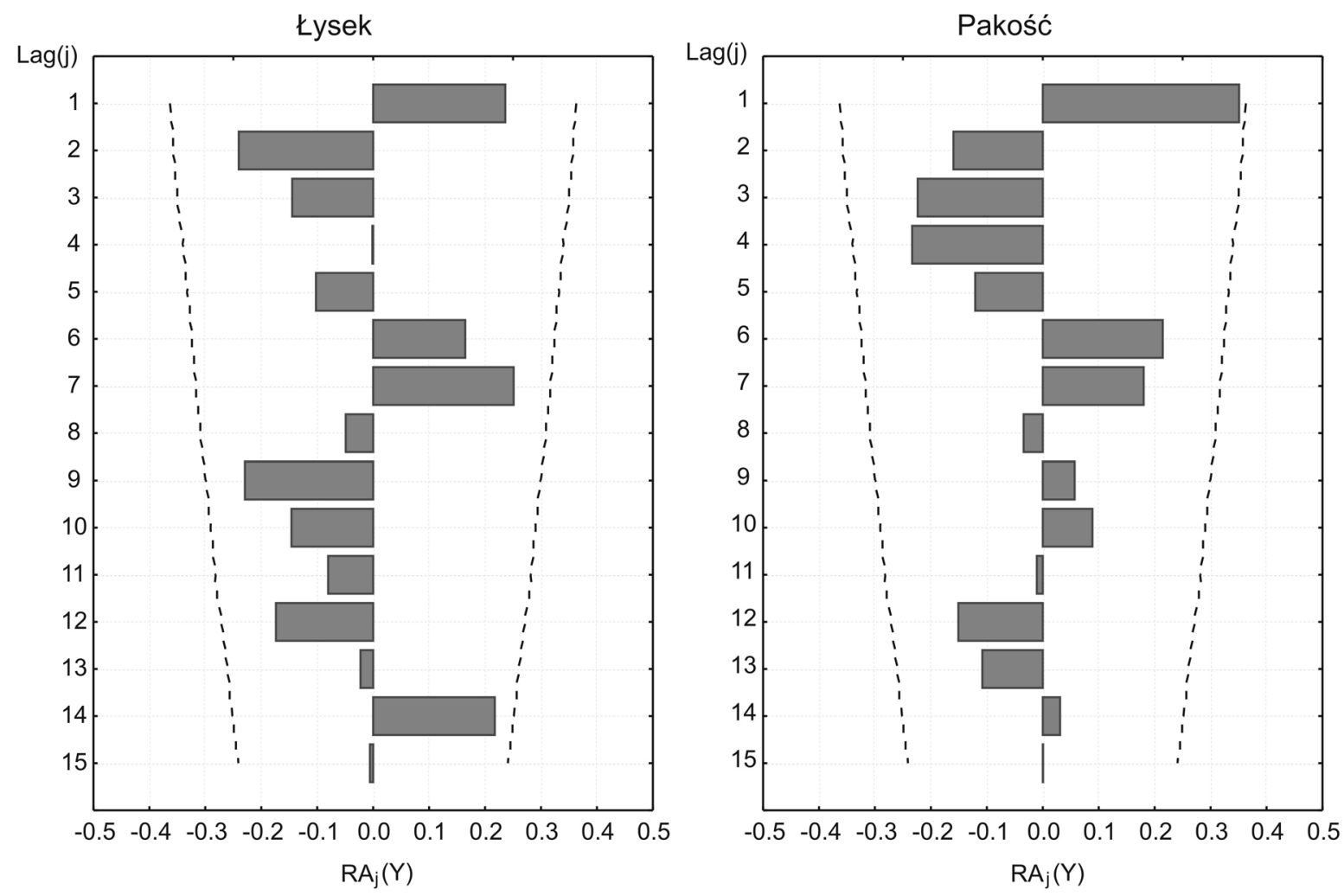

Fig. 11. Autocorrelation function of annual drought streamflow deficit in the River Noteć (1965-1990). Denotations: RAj(Y) - autocorrelation coefficient in lag equal $\mathrm{j}$, dashed line marks double value of standard error of autocorrelation coefficient 

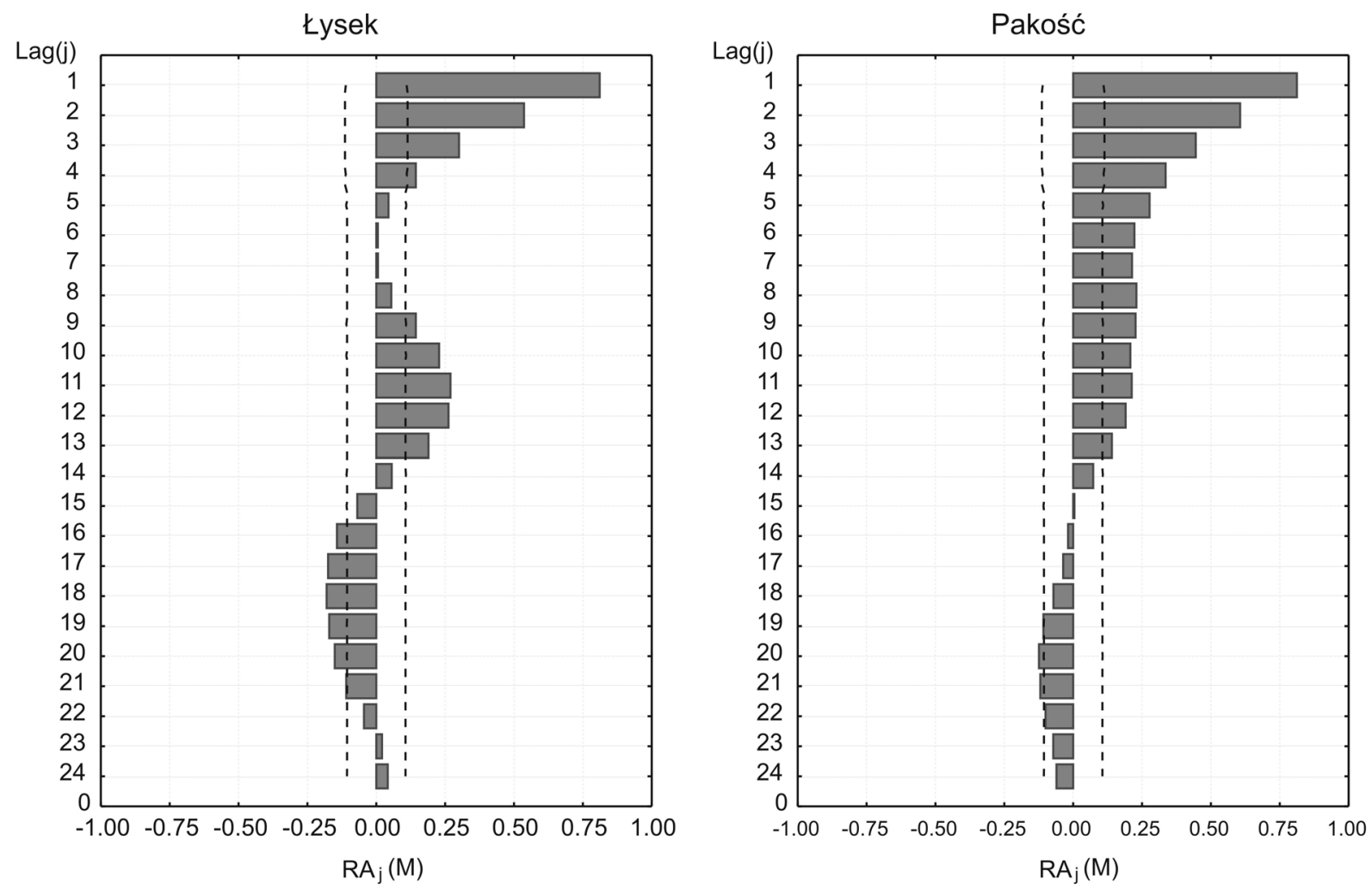

Fig. 12. Autocorrelation function of monthly drought streamflow deficit in the River Noteć (1965-1990). Denotations: RAj(M) - autocorrelation coefficient in lag equal $j$, dashed line marks double value of standard error of autocorrelation coefficient

alternately. As a result a 3-4-year weak cycle of hydrological drought and anti-drought can be inferred.

On a monthly time scale both catchments demonstrate very high inertia (Fig. 12). The first autocorrelation coefficients are strong (0.81) which suggest that drought streamflow deficit in one month has a crucial impact on its occurrence in the next. The autocorrelation function in Łysek seems to have a very clear 1-year rhythm where significant information about streamflow shortage is transmitted for 4 months. The autocorrelation function in Pakość indicates that the seasonal rhythm of inertia is much longer than 1 year. Effective transmission of water shortage impulses may last here up to 13 months. This appears to be a characteristic feature of a low-flow regime, which is highly determined by damming the water in Lake Gopło.

\section{Conclusions}

The presented analyses proved that Lake Gopło, as a dammed reservoir in the period 1965-1990, had very little impact on transformation of the low-flow regime in the upper Noteć river. The observed influence results in a lengthening of seasonal drought streamflow deficit inertia, a slight rise in minimum values of flow and decreasing streamflow deficit volumes on average.
Over the seasonal cycle, the period of reservoir replenishment was identified between March and June.

The other analysed characteristics are very similar in both gauging stations, thereby indicating a lack of any marked influence of water management in Lake Gopło on low flows in the River Noteć. It is worth pointing out that no statistically significant trend was identified in the studied multi-year period. The high multiannual variability of drought streamflow deficit appears to have a natural origin. The buffering function of lake basins has no basis in good water storage of aquifers, which demonstrate low or very low retention of a hydrologically active zone (Jokiel 1994), and also disadvantageous hydrogeological conditions (Jamorska 2015). Therefore good seasonal inertia is not transmitted into a multiannual scale.

The observed resistance of a low-flow regime to transformation under water management on the lake most likely resulted from:

- The high smoothing runoff index of Lake Gopło. If we follow Piasecki and Skowron (2014), the active retention capacity of Lake Gopło, calculated as difference of lake basin capacity in the highest and the lowest observed stage, we receive $79.1 \mathrm{hm}^{3}$. Average annual total outflow from Lake Gopło estimated by Pasławski 
and Błaszczyk (1970) reached $99.6 \mathrm{hm}^{3}$. Dividing active retention capacity by mean annual outflow, the estimated smoothing runoff index reached $79 \%$. Of course, the presented result cannot be precise because of the non-homogeneous nature of the data, however, it indicates a very high level of flow stabilization which may affect low flows especially.

- Deep alimentation by lake basin. The deepest part of Lake Gopło may drain groundwater reservoirs unavailable for river channels. During high and average flows this component of alimentation may have very small participation in total flow, although during the low flow phase its influence on runoff stabilization might be very significant.

\section{References}

Bajkiewicz-Grabowska E., 2002, Obieg materii w systemach rzeczno-jeziornych (Circulation of matter in the lake-river systems), Wydaw. UW, Warszawa, 274 pp. (in Polish, English summary)..

Grześ M., 1972, O piętrzeniu jezior w dorzeczu górnej Noteci (On the terracing of lakes in the Upper Noteć river area), Gosp. Wodn. 4: 136-137 (in Polish).

Hisdal, H., Tallaksen, L.M., Clausen, B., Peters, E. and Gustard, A., 2004, Hydrological Drought Characteristics, [in:] Tallaksen, L.M. and van Lanen, H.A.J. (eds), Hydrological Drought. Processes and Estimation Methods for Streamflow and Groundwater, Elsevier, Amsterdam: 139-198.

Jamorska I., 2015, Warunki występowania wód podziemnych południowych Kujaw (Hydrogeological conditions of southern Kujawy region), Prz. Geol. 63(10: 756-761 (in Polish, English summary).

Jokiel P., 1994, Zasoby, odnawialność i odpływ wód podziemnych strefy aktywnej wymiany w Polsce (Groundwater resources, renewal and flow in the active exchange zone in Poland), Acta Geogr. Lodz., 66-67: 1-236 (in Polish).

Jokiel P., Stanisławczyk B., 2012, Roczne odpływy maksymalne i minimalne w dorzeczach Odry i Wisły w przekroju wieloletnim (The maximum and minimum annual runoffs in river basins of the Oder and the Vistula in the multiannual period), Czas. Geogr. 83(3-4): 133-143 (in Polish, English summary).

Kendall M.G., 1984, Time Series, Oxford University Press, New York, 296 pp.

Marszelewski W., Ptak M. and Skowron R., 2011, Antropogeniczne i naturalne uwarunkowania zaniku jezior na Pojezierzu Wielkopolsko-Kujawskim (Anthropogenic and natural conditionings of disappearing lakes in the Wielkopolska-Kujawy Lake District), Rocz. Glebozn, 62(2): 283-294 (in Polish, English summary).

Marszelewski W., Kornaś M., 2012, Dammed lakes - Present state of knowledge and research requirements, Limnol. Rev. 12(4): 197-204.

Marszelewski W., Skowron R., 2011, Związki między odwodnieniem odkrywki Tomisławice a wybranymi elementami ustroju hydrologicznego jeziora Gopło (Relations between dewatering of the Tomisławice open-pit mine and selected elements of the Lake Gopło hydrological regime), Rocz. Glebozn, 62(2): 273-282 (in Polish, English summary).

Mikulski Z., 1998, Gospodarka wodna (Water management), Wydaw. Nauk. PWN, Warszawa, 202 pp. (in Polish).

Pasławski Z., Błaszczyk B., 1970, Charakterystyka hydrologiczna i bilans wodny Jeziora Gopło (Hydrological characteristics and water balance of Lake Gopło), Prz. Geof. 15(3): 251-266 (in Polish, English summary).

Piasecki A., Marszelewski W., 2014, Dynamics and consequences of water level fluctuations of selected lakes in the catchment of the Ostrowo-Gopło Channel, Limnol. Rev. 14(4): 187-194.

Piasecki A., Skowron R., 2014, Changing the geometry of basins and water resources of Lakes Gopło and Ostrowskie under the influence of anthropopressure, Limnol. Rev. 14(1): 33-43.

Smakhtin V.U., 2001, Low flow hydrology: a review, J. Hydrol. 240(3-4): 147-186.

Tomaszewski E., 2011, Defining the threshold level of hydrological drought in lake catchments, Limnol. Rev. 11(2): 81-89.

Tomaszewski E., 2012, Wieloletnia i sezonowa dynamika niżówek w rzekach środkowej Polski (Multiannual and seasonal dynamics of low flows in rivers of central Poland), Wydaw. UŁ, Łódź, 265 pp. (in Polish, English summary). 